\title{
Penanaman Nilai-Nilai Moral Pada Anak Usia Dini
}

Oleh: Lia Yuliana, M.Pd*)

\section{Pendahuluan}

Pendidikan moral diberikan di berbagai macam lembaga pendidikan, salah satunya di lembaga Pendidikan Anak Usia Dini (PAUD). PAUD atau usia pra sekolah adalah masa di mana anak belum memasuki pendidikan formal. PAUD merupakan basis pembentukan karakter moral manusia, sehingga terbentuk perilaku dan kemampuan dasar sesuai dengan tahap perkembangannya agar selanjutnya dapat menjadi warga negara yang baik. Untuk itu diperlukan penanaman nilai-nilai moral pada anak usia dini. Pentingnya penanaman nilai-nilai moral pada anak usia dini agar karakter anak dapat berkembang dengan potensi dan kemampuan anak secara optimal serta tumbuhnya sikap dan perilaku positif bagi anak. Pendidikan moral menyangkut sikap dan kepribadian, sehingga di dalam pembelajarannya tidak hanya terbatas pada pengembangan kemampuan intelektualnya saja tetapi lebih kepada pengembangan karakter, sikap, dan perilaku peserta didik

\section{Pengertian Moral}

Menurut Sjarkawi, (2006: 28), mengemukakan bahwa moral merupakan pandangan tentang baik dan buruk, benar dan salah, apa yang dapat dan tidak dapat dilakukan. Selain itu moral juga merupakan seperangkat keyakinan dalam suatu masyarakat berkenaan dengan karakter atau kelakuan dan apa yang seharusnya dilakukan oleh manusia. Menurut Jamie (2003; 15) menyatakan bahwa moral adalah ajaran baik dan buruk tentang perbuatan dan kelakuan (akhlak). Sedangkan pengertian akhlak itu sendiri oleh Al-Ghazali sebagai padanan kata moral, sebagai perangai (watak, tabiat) yang menetap kuat dalam jiwa manusia dan merupakan sumber timbulnya perbuatan tertentu dari dirinya secara mudah dan ringan, tanpa perlu 
dipikirkan clan direncanakan sebelumnya. Jamie, 2003: 24 merumuskan pengertian moral secara lebih komprehensif rumusan formalnya sebagai berikut:

1. Moral sebagai seperangkat ide-ide tentang tingkah laku dengan warna dasar tertentu yang dipegang oleh sekelompok manusia dalam lingkungan hidup tertentu.

2. Moral adalah ajaran tentang tingkah laku hidup yang berdasarkan pandangan hidup atau agama tertentu.

3. Moral sebagai tingkah laku hidup manusia yang mendasarkan pada kesadaran bahwa ia terikat oleh keharusan untuk mencapai yang baik, sesuai dengan nilai dan norma yang berlaku dalam lingkungannya.

Pendidikan moral perlu ditanamkan kepada anak sejak usia dini, sebab usia dini merupakan saat yang baik untuk mengembangkan kecerdasan moral anak.. Dari pendapat di atas, moral dimaksudkan masih sebagai seperangkat ide, nilai, ajaran, prinsip, atau norma. Akan tetapi lebih konkret dari itu, moral juga sering dimaksudkan sudah berupa tingkah laku, perbuatan, sikap atau karakter yang didasarkan pada ajaran nilai, prinsip atau norma.

Untuk menciptakan dan mengarahkan seseorang menjadi lebih bermoral maka diperlukanlah pendidikan moral, dengan pendidikan moral dimaksudkan agar manusia belajar menjadi manusia yang bermoral. Yang dimaksud dengan pendidikan moral adalah: suatu program pendidikan (sekolah dan luar sekolah) yang mengorganisasikan dan "menyederhanakan" sumber-sumber moral dan disajikan dengan memperhatikan pertimbangan psikologis untuk tujuan pendidikan. (Nurul Zuriah, 2007:22). Pendidikan moral juga dapat diartikan sebagai suatu konsep kebaikan (konsep yang bermoral) yang diberikan atau diajarkan kepada peserta didik (generasi muda dan masyarakat) untuk membentuk budi pekerti luhur, berakhlak mulia dan berperilaku terpuji seperti terdapat dalam, Pancasila dan UUD 1945. (Hamid Darmadi 2007: 56-57). 
Berdasarkan penjelasan tersebut dapat diketahui bahwa pendidikan moral bukan sesuatu yang dapat ditambahkan atau boleh dikaitkan pada pendidikan begitu saja, melainkan sesuatu yang hakiki dan bahkan menduduki tempat yang amat sentral dan strategis dalam pendidikan sehingga perlu dirancang secara khusus agar dapat mentransferkan makna pendidikan nilai moral yang hakiki menuju peradaban bangsa.

\section{Nilai-Nilai Moral}

Menurut Henry Hazlitt ( 2003: 32) mengemukakan bahwa nilai adalah suatu kualitas atau penghargaan terhadap sesuatu, yang dapat menjadi dasar penentu tingkah laku seseorang. Menurut Sjarkawi, 2005: 29 Nilai moral diartikan sebagai isi mengenai keseluruhan tatanan yang mengatur perbuatan, tingkah laku, sikap dan kebiasaan manusia dalam masyarakat berdasarkan pada ajaran nilai, prinsip dan norma.

Menurut Syaiful Bahri Djamarah (2000: 52-55) nilai moral memiliki ciri-ciri sebagai berikut:

a. Berkaitan dengan tanggung jawab kita Nilai moral berkaitan dengan pribadi manusia. Yang khusus menandai nilai moral ialah bahwa nilai ini berkaitan dengan pribadi manusia yang bertanggung jawab. Nilai-nilai moral mengakibatkan bahwa seseorang bersalah atau tidak bersalah karena ia bertanggungjawab. Dalam nilai moral kebebasan dan tanggungjawab merupakan syarat mutlak.

b. Berkaitan dengan hati nurani

Semua nilai minta untuk diakui dan diwujudkan, tetapi pada nilai-nilai moral tuntutan ini lebih mendesak dan lebih serius. Mewujudkan nilai-nilai moral merupakan "imbauan" dan hati nurani. Salah satu ciri khas nilai moral adalah bahwa hanya nilai ini menimbulkan "suara" dari hati nurani yang menuduh kita bila meremehkan atau menentang nilai-nilai moral dan memuji kita bila mewujudkan nilai-nilai moral. 


\section{c. Mewajibkan}

Nilai-nilai moral mewajibkan kita secara absolute dan dengan tidak bisa ditawartawar. Kewajiban absolute yang melekat pada nilai-nilai moral berasal dari kenyataan bahwa nilai-nilai ini berlaku bagi manusia sebagai manusia. Karena itu nilai moral berlaku juga untuk setiap manusia. Orang yang tidak mengakui nilai moral mempunyai cacat sebagai manusia.

\section{d. Bersifat formal}

Nilai-nilai moral tidak memiliki isi tersendiri, terpisah dari nilai-nilai lain. Tidak ada nilai-nilai moral yang murni, terlepas dari nilai-nilai lain. Hal itulah yang dimaksudkan bahwa nilai moral bersifat formal.

Berdasarkan penjelasan tersebut dapat diketahui bahwa di dalam moral yang menjadi tolak ukur suatu perbuatan itu bernilai baik atau buruk adalah adat istiadat yang berlaku di dalam masyarakat tertentu. Nilai-nilai moral yang bersifat objectivistic dikategorikan sebagai moral kesusilaan, seperti kejujuran, keadilan, keikhlasan, tanggung jawab dan lain-lain. Adapun nilai-nilai moral yang bersifat relativistic dikategorikan sebagai moral kesopanan, seperti berbicara secara sopan, hormat kepada orang yang lebih tua, tidak bertamu pada jam istirahat dan sebagainya. Di dalam nilai moral juga terdapat batasan-batasan berlakunya nilai tersebut. Batasanbatasan tersebut di antaranya nilai universal, berlaku bagi seluruh umat manusia bilamana dan dimanapun seperti hak asasi manusia. Nilai partikular yakni hanya berlaku bagi sekelompok manusia tertentu atau dalam kesempatan tertentu, misalnya nilai sebuah tutur kata. Nilai abadi, yakni berlaku kapanpun dan dimanapun seperti kebebasan beragama.

\section{Pengertian Anak Usia Dini}

Menurut Isjoni, 2009: 19-24, Anak usia dini adalah individu yang sedang mengalami proses pertumbuhan dan perkembangan yang sangat pesat. Anak usia dini merupakan anak yang berusia 0-6 tahun. Anak usia dini adalah individu yang sedang mengalami 
proses pertumbuhan dan perkembangan yang sangat pesat. Bahkan dikatakan sebagai lompatan perkembangan. Karena itulah, maka usia dini dikatakan sebagai usia emas, yaitu usia yang sangat berharga disbanding usia-usia selanjutnya. Anak usia dini dikenal sebagai manusia yang unik, kadang-kadang melebihi dari orang-orang dewasa yang sulit diterka, diduga, bila dilihat dari bicara, tingkah laku maupun pikirannya. Anak usia dini memiliki karakteristik tersendiri (Isjoni, 2009:24-26), diantaranya:

a. Usia 0-1 tahun

Pada masa bayi perkembangan fisik mengalami kecepatan luar biasa, paling cepat disbanding usia selanjutnya. Berbagai karakteristik usia bayi diantaranya: 1). Mempelajari keterampilan motorik mulai dari berguling, merangkak, duduk, berdiri, dan berjalan 2). Mempelajari menggunakan panca indera. 3). Mempelajari komunikasi sosial.

b. Usia 2-3 tahun

Pada usia ini memiliki karakteristik yang sama pada usia selanjutnya, secara fisik mengalami pertumbuhan yang sangat pesat. Karakteristik khusus pada usia ini antara lain; 1). Anak sangat aktif mengeksplorasi benda-benda yang ada disekitarnya. 2). Mulai mengembangkan kemampuan berbahasa. 3). Mulai mengembangkan emosi.

c. Usia 4-6 tahun

Karakteristik usia ini antara lain:

Berkaitan dengan perkembangan fisik, anak sangat aktif melakukan kegiatan. 2). Perkembangan bahasa semakin baik. 3). Perkembangan kognitif sangat pesat. 4). Bentuk permainan anak masih bersifat individu.

\section{Penanaman Nilai-Nilai Moral Pada Anak Usia Dini}

Hamid Darmadi, (2007: 56-57) Penanaman Nilai-Nilai Moral Pada Anak Usia Dini dapat dilakukan dengan berbagai macam metode yaitu : 


\section{Metode Bermain}

Melalui metode bermain karena dengan bermain anak-anak untuk mampu bersosialisasi dengan orang lain. Bermain memberikan kesenangan kepada anakanak, mereka dapat menuangkan imajinasi yang ada di pikiran secara bebas melalui bermain. Dengan bermain banyak nilai-nilai moral dan sosial yang dapat diajarkan, diantaranya:

a) Mengajarkan kepada anak agar mau bersosialisasi dan mampu bekerjasama dengan teman-teman sepermainan.

b) Mengajarkan kepada anak agar memiliki sikap tenggang rasa, menolong sesama yang sedang membutuhkan.

c) Mengajarkan kepada anak untuk mau berbagi bersama teman serta memiliki rasa peduli kepada orang lain.

d) Mengajarkan tata bicara yang sopan, baik, dan benar kepada anak-anak.

e) Memperkenalkan kepada anak tentang berbagai macam aturan baik yang ada di keluarga, lingkungan, sekolah maupun di jalan.

f) Melatih anak-anak untuk menaati peraturan-peraturan tersebut.

g) Mengajarkan kepada anak untuk belajar menerima konsekuensi atau akibat jika melanggar peraturan tersebut (wawancara dengan pendidik dan observasi

\section{Metode Bercerita}

Melalui cerita dapat menyampaikan pesan-pesan atau informasi moral yang dapat menambah pengetahuan anak tentang nilai-nilai moral yang berlaku di masyarakat. Setelah bercerita dapat menyampaikan pesan-pesan moral misalnya sikap rendah hati, kejujuran, tidak boleh membantah, menyayangi orang tua, selalu mendengar nasehat orang tua, tidak boleh kasar dan membentak orang tua, sikap toleransi harus kita tanamkan pada diri kita masing-masing, guna membantu orang tua, saudara, teman, tetangga dan orang lain yang membutuhkan. Selain itu juga menanamkan rasa kecintaan terhadap orang lain. Anak-anak harus belajar menyayangi orang lain, tidak hanya keluarga tetapi semua orang 


\section{Metode Pemberia Tugas}

Nilai moral yang dapat disisipkan melalui metode pemberian tugas individu antara lain:

a) Melatih kesabaran seorang anak, mengajari untuk bertanggung jawab terhadap apa yang telah menjadi tugasnya.

b) Belajar untuk menaati aturan yang telah disepakati bersama.

Nilai moral yang dapat disisipkan melalui metode pemberian tugas secara kelompok antara lain:

a) Mendorong anak untuk selalu bekerja sama.

b) Menumbuhkan kemauan anak untuk bersosialisasi dengan orang lain

\section{Metode Bercakap-cakap}

Bercakap-cakap mempunyai makna penting bagi perkembangan anak, sebab dapat meningkatkan keterampilan komunikasi dengan orang lain. Dengan bercakapcakap banyak sekali pengetahuan yang dapat diberikan kepada anak, karena pada dasarnya anak suka sekali bertanya. Melalui bercakap-cakap pendidik mengajarkan aturan, nilai, dan norma yang berlaku di masyarakat, agar anak dapat menjalin hubungan dan dapat diterima oleh lingkungan sosial sekitar dengan baik. Misalnya bila anak bertemu dengan orang yang lebih tua, pendidik mengajarkan untuk:
a) memberi salam dengan tangan kanan
b) mencium tangan orang yang lebih tua
c) mengucap selamat pagi/siang/sore/malam
d) mengucap salam
e) bersikap sopan dengan bicara yang baik
f) bila bicara harus memandang lawan bicara dengan pandangan yang sopan 


\section{Cara Pelaksanaan Penanaman Nilai-Nilai Moral Pada Anak Usia Dini}

Cara Pelaksanaan Penanaman Nilai-nilai moral pada anak usia dini dapat diselenggarakan melalui Pendidikan Anak Usia Dini (PAUD) diselenggarakan sebelum jenjang Sekolah Dasar. PAUD dapat diselenggarakan melalui jalur pendidikan formal, non formal, dan/atau informal. PAUD pada jalur pendidikan formal berbentuk Taman Kanak-kanak (TK) dan Raudatul Athfal (RA). PAUD pada jalur pendidikan non formal berbentuk Kelompok Bermain (KB), Taman Penitipan Anak (TPA), dan Satuan PAUD Sejenis (SPS), (Nurul Zuriah, 2007: 23) pada jalur pendidikan non formal cara penanaman nilai-nilai moral pada anak usia dini bisa dilakukan melalui pendidikan keluarga dan pendidikan yang diselenggarakan oleh lingkungan. Dalam pendidikan non formal tidak memiliki kurikulum baku, sehingga dapat menggunakan penggunaan metode pembelajaran yang sesuai dengan karakter anak akan dapat memfasilitasi perkembangan berbagai potensi dan kemampuan anak secara optimal serta tumbuhnya sikap dan perilaku positif bagi anak.

Pada jalur pendidikan formal cara penanaman nilai-nilai moral pada anak usia dini bisa dilakukan melalui kegiatan pembelajaran dengan jadwal tatap muka yang ditentukan yaitu meliputi :

1. Persiapan Kegiatan Pembelajaran

Persiapan kegiatan pembelajaran dengan menggunakan: 1). Media pembelajaran yang dipergunakan dalam penanaman nilai-nilai moral terdiri dari media pembelajaran sederhana dan media pembelajaran tradisional dan alat permainan edukatif (APE), 2). Menggunakan buku pegangan sebagai acuan untuk mengajarkan pendidikan moral, menggunakan segala macam buku yang berkaitan dengan pendidikan moral untuk anak usia dini. Salah satu buku yang digunakan adalah buku tentang metode pengembangan moral dan nilai agama. 


\section{Pelaksanaan Kegiatan Pembelajaran}

a. Penataan lingkungan bermain

Lingkungan main disiapkan tergantung dari rencana pembelajaran yang akan dilakukan. Kemudian alat dan bahan main, alat dan bahan main yang dipersiapkan disesuaikan dengan rencana dan tujuan pembelajaran serta usia dan perkembangan anak. Selain itu mainan juga dibuat bervariasi dan semenarik mungkin, tujuannya adalah untuk menarik perhatian siswa.

b. Kegiatan Inti Pembelajaran

Guru memberi dukungan kepada anak didik, membantu anak didik yang membutuhkan bantuan, serta mendorong anak didik untuk mencoba cara lain agar anak dapat berkreasi. Kemudian mengumpulkan hasil kerja anak lengkap dengan nama dan tanggal. Tidak lupa guru selalu mengingatkan anak didiknya agar tidak lupa membereskan sendiri alat mainnya.

c. Kegiatan Penutup

Setelah kegiatan inti usai, guru menanyakan kembali kegiatan yang baru saja mereka lakukan. Tujuannya untuk melatih daya ingat anak-anak dan memperluas perbendaharaan kata.

\section{Penutup}

Pendidikan memiliki peranan yang sangat penting dalam mewujudkan warga negara yang berkepribadian tinggi dan berakhlak mulia, sehingga dapat menciptakan SDM yang berkualitas tinggi. Peranan pendidikan tersebut kapan saja sangat dibutuhkan, lebih-lebih mengingat salah satu permasalahan bangsa yang sangat mengkhawatirkan saat ini adalah moral dan akhlak. Perlunya penanaman nilai-nilai moral, baik di lingkungan keluarga, sekolah dan masyarakat secara keseluruhan 
Pada masa usia dini dimanfaatkan untuk menanamkan nilai-nilai moral, untuk perkembangan serta kecerdasan moral anak. Pendidikan moral diartikan sebagai suatu konsep kebaikan yang diberikan atau diajarkan kepada peserta didik untuk membentuk budi pekerti luhur, berakhlak mulia dan berperilaku terpuji seperti terdapat dalam Pancasila dan UUD 1945.

Di dalam penanaman nilai-nilai moral pada anak usia dini dapat menggunakan berbagai metode yaitu metode bermain, bercerita, pemberian tugas dan bercakapcakap, penggunaan metode tersebut dapat disesuaikan dengan kondisi dan karakter anak yang menjadi sumber pertimbangan utama. Sebab metode akan sangat berpengaruh terhadap keberhasilan penanaman nilai-nilai moral pada anak usia dini. Cara pelaksanaan penanaman nilai-nilai moral pada anak usia dini, pada jalur pendidikan non formal cara penanaman nilai-nilai moral pada anak usia dini bisa dilakukan melalui pendidikan keluarga dan pendidikan yang diselenggarakan oleh lingkungan, pada jalur pendidikan formal dapat dilakukan melalui kegiatan pelaksanaan pembelajaran meliputi kegiatan lingkungan bermain, kegiatan inti dan kegiatan peutup.

\section{DAFTAR PUSTAKA}

Hamid Darmadi. (2009). Dasar Konsep Pendidikan Moral. Bandung: ALFABETA Henry Hazlitt. (2003). Dasar-dasar Moralitas. Yogyakarta: Pustaka Pelajar Isjoni. (2009). Model Pembelajaran Anak Usia Dini. Bandung: ALFABETA Jamie C. Miller. (2003). Mengasah Kecerdasan Moral Anak. Bandung: KAFIA Nurul Zuriah. (2007). Pendidikan Moral \&. Budi Pekerti dalam perspektif Perubahan.

Jakarta: Bumi Aksara.

Sjarkawi. (2005). Pembentukan Kepribadian Anak. Jakarta: Bumi Aksara.

Syaiful Bahri Djamarah. (2000). Guru dan Anak Didik Dalam Interaksi Edukatif. Jakarta:

PT Rineka Cipta 